\title{
6 A MURDER MYSTERY IN BLACK AND BLUE: THE MARKETING, DISTRIBUTION, AND CULT MYTHOLOGY OF SNUFF IN THE UK
}

\section{Mark McKenna}

n the USA, in 1976, theatrical screenings of Michael and Roberta Findlay's Snuff triggered a month-long FBI investigation into whether or not the film depicted an actual murder in its final scene. ${ }^{1}$ It was therefore almost inevitable that the film's eventual release in the more conservative British market would be problematic.

Some six years before it was scheduled for a release on UK home video in 1982, a US investigation had ruled that the murder depicted in the film was quite clearly simulated. ${ }^{2}$ However, Snuff entered into an increasingly censorious climate in the UK following concerns over the advertising used to promote home video releases of horror and exploitation films, which, because of a loophole in the law, were not legally required to be submitted to the British Board of Film Censors for certification. The release of uncensored films such as SS Experiment Camp (Sergio Garrone, 1976), ISpit on Your Grave (Meir Zarchi, 1978), and The Driller Killer (Abel Ferrera, 1979) would prompt an influential article in The Sunday Times in which journalist Peter Chippendale warned of the "video nasties": graphic horror videos that he alleged were "far removed from the traditional horror film ... dwell[ing] on murder, multiple rape, butchery, sado-masochism, mutilation of women and Nazi

\footnotetext{
${ }^{1}$ See David Kerekes and David Slater, Killing for Culture: An Illustrated History of Death Film from Mondo to Snuff (London: Creation Books, 1995).

${ }^{2}$ Ibid.; Mikita Brottman, Offensive Films (Westport: Vanderbilt University Press, 2005): 79-95.
} 
atrocities." ${ }^{3}$ These are the criteria which would soon come to define the "video nasties," and of which Snuff would be emblematic. ${ }^{4}$

This chapter examines the cult mythology that has developed around Snuff in the UK, paying particular attention to the role of its distributor, Astra Video, and the role of horror film fan communities in furthering and shaping that mythology. The chapter is ultimately concerned with the nationally specific context in which Snuff was first distributed in Britain, and more specifically, how the film's UK video release has become the subject of heated and, at times, vituperative argument, among fans and collectors of the video nasties.

Snuffs murky UK distribution history is littered with inconsistencies and discrepancies, so as a means of being as clear as possible, what follows is divided into two sections, both of which investigate the distribution of Snuff in the UK and its subsequent legacy as a collector's item among video-nasty fans. First, drawing on contemporaneous reports that featured in the video consumer press, the video trade press and national newspapers in the 1980s, it constructs a chronological history of Snuff in the UK. From there, in the second section, discussion will move to consider those parts of Snuffs British distribution narrative that have proven most contentious and speculative in video collecting communities, and will address the gaps in the formerly outlined history that have prompted debate and furthered the mythology surrounding the film. The chapter will conclude by considering the importance of the contested British history of Snuff within and beyond collector culture. Indeed, while the mythology surrounding snuff films is typically positioned as being cross-cultural, and most frequently relates back to the question of whether or not they exist, ${ }^{5}$ there is also a nationally specific mythology surrounding the distribution of Snuff in the UK. This chapter aims to examine certain elements of that mythology.

\section{Made in Croydon ... where life is cheap! A chronological history}

The release of Snuff in Britain has been discussed at some length by Julian Petley in his contribution to Unruly Pleasures: The Cult Film and Its Critics: "Snuffed out':

\footnotetext{
${ }^{3}$ Peter Chippendale, "How High Street Horror Is Invading the Home," The Sunday Times, May 23, 1982. ${ }^{4}$ The cultural history and legacy of the video nasties has been widely discussed in academic research. See, for example, The Video Nasties: Freedom and Censorship in the Media, edited by Martin Barker (London: Pluto Press, 1984); Kate Egan, Trash or Treasure? Censorship and the Changing Meanings of the Video Nasties (Manchester: Manchester University Press, 2007); and Julian Petley, Film and Video Censorship in Modern Britain (Edinburgh: Edinburgh University Press, 2011).

${ }^{5} J u l i a n$ Petley, “'Snuffed Out': Nightmares in a Trading Standards Officer's Brain,” in Unruly Pleasures: The Cult Film and Its Critics, edited by Graeme Harper and Xavier Mendik (Guilford: FAB Press, 2000).
} 
Nightmares in a trading standards officer's brain."' However, the film's distribution history has rarely been acknowledged within the academy ${ }^{7}$ and most discussion of its troubled dissemination has been restricted to either coffee table volumes or has appeared in online discussions on video collector forums such as Pre-Cert Video. ${ }^{8}$ In this material, there is much debate around whether or not the film was indeed ever "officially" released by a named distributor onto the UK market. So conflicting are the arguments that the film's "true" distribution history remains in doubt. ${ }^{9}$

One of the arguments put forward is that Croydon-based Astra Video-a company known in the trade for its horror videos ${ }^{10}$ (including some subsequently banned as video nasties) and which had originally promoted Snuff as one of its forthcoming titles in 1982 - in actuality, never released it, and that the film only ever circulated in Britain as a pirated cassette. This is an argument evinced in the book See No Evil: Banned Films and Video Controversy, which was cowritten by prolific fanzine publisher David Kerekes, as well as in Shock! Horror!: Astounding Artwork from the Video Nasty Era and The Art of the Nasty, in addition to the DVD box set Video Nasties: The Definitive Guide(Jake West, 2010); the latter of which were all produced under the purview of recognized cultural intermediaries on the video-nasty era and moderators of the Pre-Cert forum, Marc Morris, and Francis Brewster. ${ }^{11}$ These works collectively purport that while Astra had initially planned to release the film, exhibiting the tape at a video trade show in 1982, the company

\footnotetext{
${ }^{6}$ Ibid., 210-19.

${ }^{7}$ Petley touches very lightly on these issues, but his article is mostly concerned with the birth of the snuff mythology, and the way that the mythology has been framed in British newspapers. Ibid., 211.

${ }^{8}$ The moniker "pre-cert" explicitly refers to video-cassettes released in Britain prior to 1984, before the introduction of the Video Recordings Act (VRA), and thus before it was a legal requirement for all films released on video to be "certified"- deemed "suitable" for audiences-by the British Board of Film Censors. These videos have become increasingly sought after and the Pre-Cert Forum has become an important hub for collectors of these cassettes and related ephemera.

${ }^{9}$ At the time of writing, a simple search for "Snuff" on the Pre Cert Forum returns 478 threads containing thousands of posts, with many of these threads dedicated entirely to the debates that persist around it.

${ }^{10}$ One of Astra's notable early releases, The Best of Sex and Violence (Various, 1981)-which was a compilation of salacious clips from a range of exploitation titles-set the bar for what was to follow.

${ }^{11}$ David Kerekes and David Slater, See No Evil: Banned Films and Video Controversy (Manchester: Headpress, 2000); Marc Morris, Harvey Fenton, and Francis Brewster, Shock! Horror!: Astounding Artwork from the Video Nasty Era (Guilford: FAB Press, 2005); Nigel Wingrove and Marc Morris, The Art of the Nasty (Surrey: FAB Press/Salvation, 2nd edition, 2009). Marc Morris is perhaps the most notable name of all here. He is one of the founders of the Pre-Cert forum (along with Francis Brewster), is known in the fan community for his extensive early video collection, and was the producer of Video Nasties: The Definitive Guide and Video Nasties: The Definitive Guide Part 2 (which he also distributed through Nucleus Films: a company he co-owns with film director, Jakes West). Significantly, Morris' collection is frequent seen the background of the talking heads segments of the Video Nasties documentaries.
} 
withdrew the release in response to the mounting pressure that was being levied against the video industry, following advice from their legal representation. ${ }^{12}$ However, seeing as though copies of Snuff did circulate, albeit without Astra's branding (or any company logo for that matter), some commentators and collectors have debated that Astra may well have been responsible for the release after all, but had "taken the copies already prepared and released them ... without distributor information on them (to make cash and avoid the law)."13 In light of these debates, this section scrutinizes trade and consumer press of the 1980s to trace this contested distribution history of Snuff, and to shed light onto areas of conflicting discourse that have contributed to the shaping of Snuffs mythology in British collector circles.

Some aspects of the history put forward in See No Evil, Shock Horror, Art of the Nasty, and Video Nasties: The Definitive Guide can be verified via the examination of contemporaneous press reportage. An article published in Television and Video Retailer confirms both the presence of Snuff at the trade show alluded to above and Astra's involvement in its release, reporting that the film was showcased by Astra at Manchester's Northern Software Show (NSS) on May 23 and 25, 1982, and that "trade appeared to be booming." 14 Indeed, the film was apparently so popular that Astra's CEO, Mike Behr, claimed that the company had already taken orders for 2,500 units by the end of the first day, ${ }^{15}$ while the Daily Express, reporting on May 28, confirmed the anticipated widespread distribution of the film: "A new commodity will be available on your high street next week-a film called 'Snuff' which anyone will be able to buy over the counter at some of the 12,000 video shops throughout Britain." ${ }^{16}$

From these reports, it would appear that Astra had all intentions of releasing Snuff. Moreover, given the film's notoriety, the reports of the film's popularity would also appear credible, seeing as though Astra's other horror and exploitation titles (many of which, as with Snuff, were licensed from the US distributor Wizard Video) were performing similarly well at trade shows throughout the country. ${ }^{17}$ However,

\footnotetext{
${ }^{12}$ Kerekes and Slater, See No Evil, 48, 254; Marc Morris et al., Shock Horror! 239; Wingrove and Morris, The Art of the Nasty, 29; Kim Newman upholds this argument in his contribution to Video Nasties: The Definitive Guide.

${ }^{13}$ Bigandy, “The Evolution of Astra's SNUFF," June 7, 2010, accessed June 8, 2014, http://pre-cert.co.uk/ forum/showthread.php?t=16401\&highlight=blue+snuff. See also Kerekes and Slater, See No Evil, 254. ${ }^{14}$ Anon., "Snuff Snuffs It," Television and Video Retailer, June 1982, 24.

${ }^{15}$ Anon., "Protests Expected over Astra Release of US 'Snuff' Movie," Video Business 2, no. 8, June (1982): 6.

${ }^{16}$ Tony Dawe, "This Poison being Peddled as Home Entertainment," The Daily Express, May 28, 1982, 7.

${ }^{17}$ Television and Video Retailer ran a feature on the London Heathrow Software Show, which took place earlier in the year, and reported that "Mike Behr, Astra's managing director, says that over 1,000 units of I Spit on Your Grave were sold and that Schlock, 'a monster comedy about an ape-man who goes bananas' [...] saw around 900 sales." See Anon., "The Wizard from LA," Television and Video Retailer, June 1982, 52.
} 
as momentum against the video nasties escalated from the press, ${ }^{18}$ releasing a film such as Snuff, which purported to feature a genuine murder, could have mobilized the kinds of legal action that Behr, in an earlier interview, had scoffed at: "There's no censorship laws on video at all. What can they [the authorities] do about it?"19 Following the aforementioned article in the Daily Express which drew on Snuffs apparent "scenes of rape and mutilation and murder so realistic that the cover asks: 'are the killings in the film for Real?' "20 Astra was forced to backtrack on any previous claims about Snuff's supposed veracity: a factor that Behr tried to hype at the NSS, by "refusing to preview [scenes from] the film" to potential clients. ${ }^{21}$ Obviously feeling the turning tide, and in response to the negative publicity, Behr felt it necessary to clarify his position with the industry magazine Video Business the week after the NSS, explaining that "of course [Snuff is] not a real snuff movie... It's a publicity stunt." He continued, explaining that, because of the rising video-nasty controversy he could see "[the] release of the film lead[ing] to [legal] problems" and, for that reason, his company would "only be keeping the film on the market for about a month." 22

What should be clear is that, by June 1982, Behr was at least appearing to exercise a certain degree of caution regarding the release of Snuff. By opting for a limited release, it is arguable that he was at once recognizing the profits that could be amassed from stocking a controversial film with wide media exposure, but by the same token restricting its release to try to circumvent any future legal consequences. Behr's trepidation certainly demonstrates a restraint at odds with how he had originally intended to promote the film.

In the very same issue of Video Business, Astra had taken out a full-page advertisement which promoted its release of Snuff alongside another visceral horror film, and future video nasty, Blood Feast (Figure 6.1). The ad, which was based on material that had been used to promote the films' US video releases, was highly sensational: with grisly painted artworks for each film-a man holding a meat clever over the bloodied corpse of young woman for Blood Feast, and a crazed psychopath wielding an axe over the image of a woman's bloodied hands for Snuff-were positioned side-by-side under the deliberately provocative banner: "WALL-TO-WALL GORE-Two powerful releases from ASTRA." In a style reminiscent of a grind house double-bill, the advert emphasized both films' graphic and visceral qualities and, significantly, their

\footnotetext{
${ }^{18}$ Petley, Film and Video Censorship in Modern Britain, 23-43.

${ }^{19} \mathrm{Behr}$ cited in Chippendale, "How High Street Horror Is Invading the Home." See also John Martin, Seduction of the Gullible: The Truth Behind the Video Nasty Scandal (Liskeard: Stray Cat Publishing, 2007): 14.

${ }^{20}$ Dawe, “This Poison Being Peddled as Home Entertainment," 7.

${ }^{21}$ Anon., "Snuff Snuffs It," 24.

${ }^{22}$ Anon., "Protests Expected over Astra Release of US 'Snuff' Movie," 6.
} 


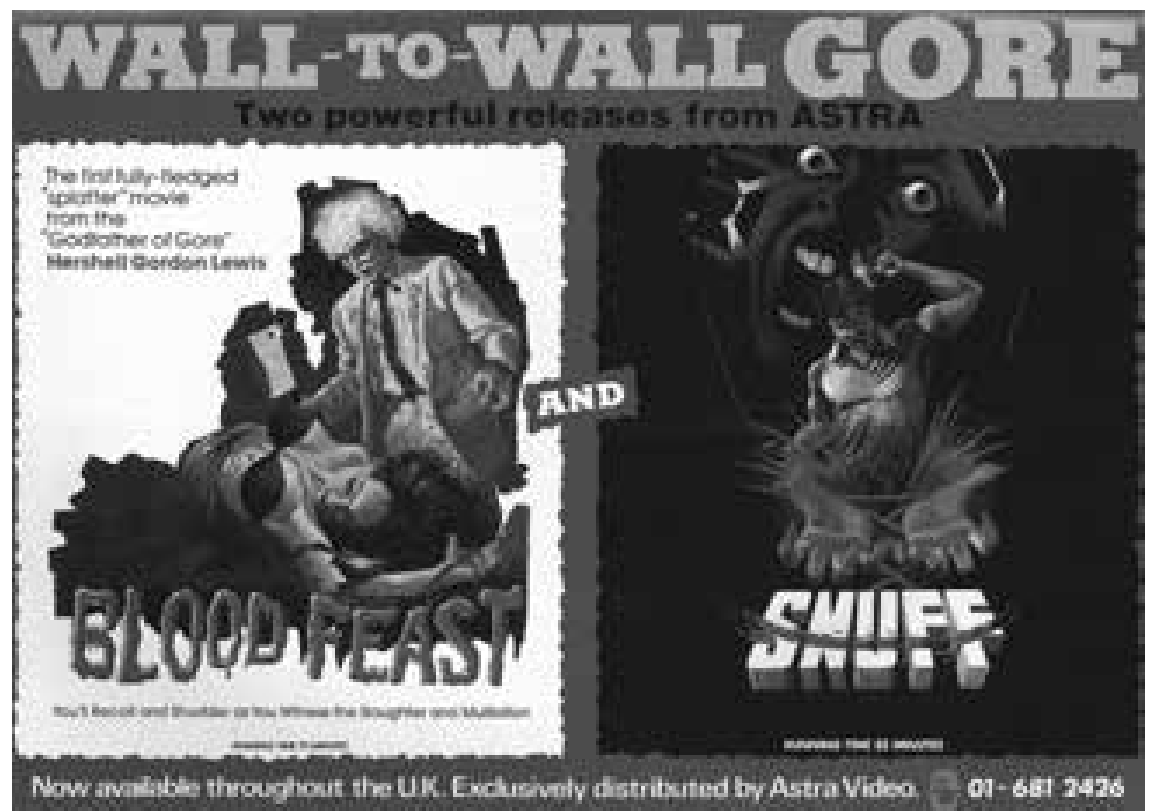

FIGURE 6.1 "Wall-to-Wall Gore"-Astra Video promotes Snuff alongside Blood Feast.

"power" to affect the viewer, ${ }^{23}$ working to contradict whatever cautiousness Behr was trying to exercise elsewhere.

However, for all that this particular advert seemed to delight in provocation, by the following issue of Video Business, the magazine reported that Astra had withdrawn the film..$^{24}$ Listed simply under the headline "SNUFF", the company stated that, in response to "attacks by the British press," and as a company "[p] roud of its reputation for integrity and honesty," Astra wanted to avoid any confusion that had arisen regarding Snuffs supposed scenes of real live death. While the company believed that the film did not show "any unacceptable scenes

\footnotetext{
${ }^{23}$ As Julian Petley has argued, the video nasties were often portrayed by the media as "potential or actual causes of violence." Julian Petley, “Are We Insane?': The 'Video Nasty' Moral Panic," Recherches sociologiques et anthropologiques (2012) http://rsa.revues.org/839. For more information about the media effects debate surrounding video nasties see, for instance: Martin Barker, The Video Nasties; Guy Cumberbatch, "Legislating Mythology: Video Violence and Children," Journal of Mental Health 3, no. 4 (1994): 485-94; Kenneth Thompson, Moral Panics (London: Routledge, 1998): 90-91; and James Kendrick, "A Nasty Situation: Social Panics, Transnationalism and the Video Nasty," in Horror Film: Creating and Marketing Fear, edited by Steffen Hantke (Jackson: University Press of Mississippi, 2004): 153-72.

${ }^{24}$ Anon., “DPP Ponders the Case Against 'Horror' Videos," Video Business 2, no. 9, mid-June (1982): 1.
} 
of violence," it felt that the film had "been sensationalised [by the press] into something that it is not." 25

At this stage, a public announcement recognizing the film's fictional content would seem to have functioned as a restorative measure, and by mid-1982, it would seem that Astra had attempted to sever all ties with the film. However, by September 12, The Sunday Times reported that Snuff had indeed made its way onto market. In the article, Behr, in defense of himself and his company, claimed that the film the Sunday Times purported to be Snuff simply could not have been Snuff, because the master copy had reportedly been returned to the US before any copies of film had actually been made for UK distribution. Behr also claimed, somewhat tenuously, that the film that the Sunday Times purported to be Snuff was "not Snuff at all," but rather "a compilation of various cuts under the snuff label."26

However, in spite of Behr's insistence, the film had in fact made its way on to UK market, and irrespective of his claims, to the contrary, the content had remained unchanged. As noted previously, however, neither the packaging of the cassette (which reworked the same image Astra had used to promote the film in Video Business) or, indeed, the label on the cassette itself, made any reference to Astra at all. These factors have contributed to the assumption that this was an unofficial, bootlegged, release of the film; a position reinforced by Behr in his retrospective interview for Shock Horror in 2005. ${ }^{27}$ Ironically, by February 1983, the consumer magazine, Video Viewer, reported that the Department of Public Prosecutions (DPP) was considering prosecuting Astra for allowing copies of Snuff to be leaked onto the market, which has worked to continue those debates concerning Astra's apparent distance from the release of Snuff, namely, because Astra was targeted by the DPP despite there being no conclusive evidence about the company's involvement in the distribution. ${ }^{28}$

All these factors have featured prominently in discussions among video collectors concerning the distribution of Snuff in Britain. In fan communities, questions are repeatedly asked about Astra's involvement in the circulation of the film. This had led to the repeated examination of the minutia of detail surrounding the film: from the video's contentious historical timeline, to the cassette and its packaging. All of these factors have been scrutinized in an attempt to secure the provenance of Snuff. In light of this, the next section will examine the major debates that have taken place.

\footnotetext{
${ }^{25}$ Astra press release, "SNUFF," Video Business 2, no. 9, Mid-June (1982): 4.

${ }^{26}$ The Sunday Times, September 12, 1982.

${ }^{27}$ Morris et al. Shock Horror!, 239.

${ }^{28}$ Anon., "Tougher Times on the Way for Video Nasty Distributors," Video Viewer 2, no. 8 (1983): 8.
} 


\section{Snuff or "F" for "fake"?: Key debates, speculation, and cultures of collecting}

According to much discussion in books and online, the release of Snuff that Astra intended to market to the public prior to withdrawing it, had different artwork to the version that eventually found its way onto the high street. It is worth unpicking these differences, for they have proven important factors within video collecting culture.

In both Astra's intended original release (hereby referred to as the "official" version) and in the assumed pirated release (hereby, "unofficial"), the central imagery on the front of both tape covers remains the same: a maniacal figure is depicted wielding an axe over a pair of female hands that are bound in rope and bleeding from the wrists. The background of the image shows a screaming face between two sets of studio lights, indicating the iconography of the film set that would become central to the film's mythological status. ${ }^{29}$ The film's title is positioned beneath these images, capitalized in 3-D lettering, with a bloodied slash running across the middle. The artwork from the official release frames these images in a pale-blue border, which has led to the nickname "blue-sleeve Snuff" among collectors. On this version, the legend "the original legendary atrocity shot and banned in New York" is emblazoned in red typeface at the top of the cover, and Astra's "AV" insignia, along with the words "Cult Video," are displayed prominently on the front, spine, and rear of the cover.

The "Cult Video" label is particularly significant, for it indicates that the artwork of the blue-sleeved version is a replication of that used on the US release of the film by Wizard Video, the company from which Astra had licensed it. In fact, a similar styling is present across two other releases that Astra acquired from Wizard, including Blood Feast (which has a red border) and I Spit on Your Grave (which has yellow border) (Figure 6.2). The front cover of the blue-sleeved Snuff clearly identifies "Cult Video distributed exclusively in the UK by Astra Video" and provides company credits alluding to Monarch Films, the company responsible for the film's theatrical distribution in the US. The rear of the cover depicts a scaled-down copy of the central cover image above a synopsis detailing the controversial nature of the film's subject matter. Tellingly, the synopsis ends with the rhetoric "are the killings in this film real? You be the judge!" The rear also displays a copyright prosecution notice that verifies the legitimacy attached to this particular release: namely, that it was a genuine Astra product.

\footnotetext{
${ }^{29}$ The background image was reused a number of times by different companies in different contexts. The chief example is Media's release of the Mexican horror film, Demonoid (Alfredo Zacarías, 1979), which positions the blue screaming face behind an image of a sword-wielding demon standing tall, with two scantily-clad women at its feet.
} 

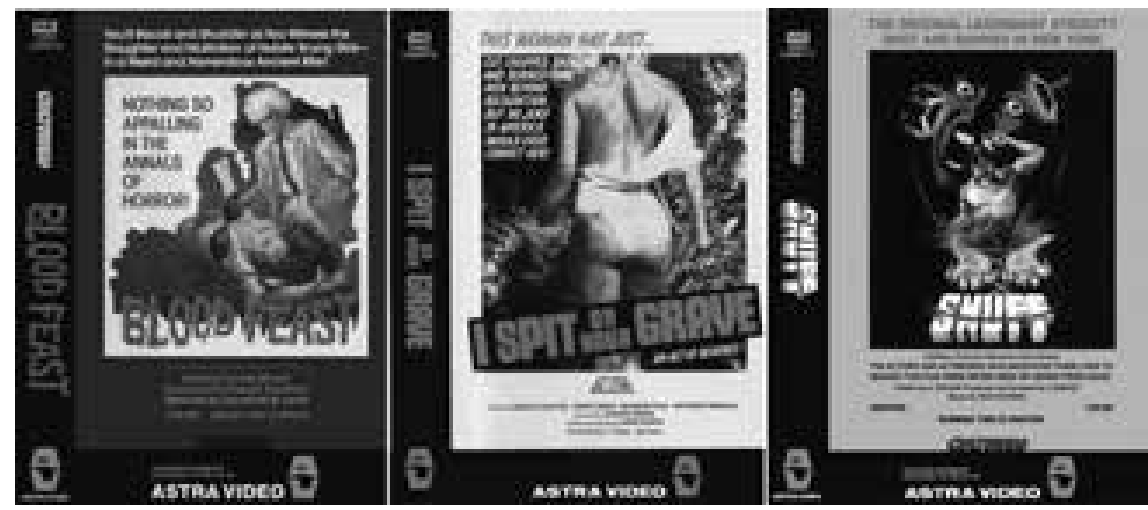

FIGURE 6.2 The respective Astra Video covers for Blood Feast, I Spit on Your Grave and "blue-sleeve" Snuff.

Comparatively, the "unofficial" release lacks any form of insignia other than a vertical strip on the video spine to indicate that it is a "VHS" cassette. The cover imagery lacks the blue border of the "official" release and is rendered primarily in black; hence, video collectors designating it "black-sleeve Snuff" (Figure 6.3). The artwork for this version comprises the entire front of the cassette and the capitalized legends "the original legendary atrocity shot and banned in New York" and "the actors and actresses who dedicated their lives to making this film were never seen or heard from again" are emblazoned in yellow typeset at the top and bottom of the video cover (the latter is also present on the bluesleeved version, although is less pronounced). The synopsis on the rear of the packaging is replicated from the blue-sleeved version verbatim, albeit with the title Snuff capitalized in red. The black-sleeved version of the tape therefore contains far less information than its "official" counterpart; a factor which, without question, served to heighten the mystique surrounding its release into the UK marketplace.

The presence of these two different versions of the same film has retrospectively led video-nasty collectors to assume that Astra did in fact release the film, albeit as a "bootleg," and in spite of several protestations from Behr, who has claimed that he had nothing to do with it, and, contrarily, that the film was distributed by a "well-known video piracy gang." ${ }^{30}$ Certainly, it is the noted differences between the blue-sleeve and black-sleeve versions that have become the basis for most debate. Such arguments are typical of video-nasty collectors who continuously discuss the authenticity of tapes released, the companies that released them, and

${ }^{30}$ Behr quoted in Morris et al., Shock Horror!, 239. 


\section{THE ORIGINAL LEGENDARY ATROCITY SHOT AND BANNED IN NEW YORK}

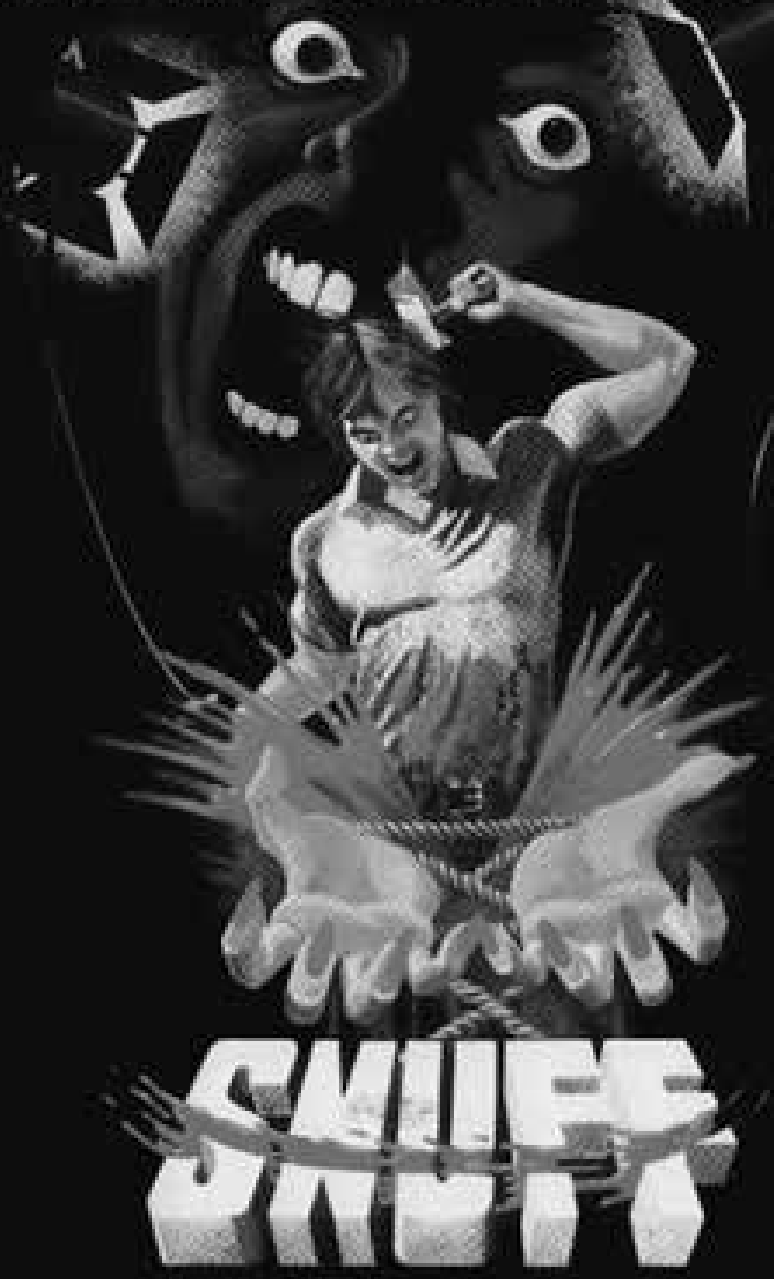

THE ACTORS AND ACTRESSES WHO DEDICATED THEIR LIVES TO MAKING THIS FILM WERE NEVER SEEN OR HEARD FROM AGAIN.

FIGURE 6.3 The "unofficial," minimalist, "black-sleeve" version of Snuff. 
the circulation of pirates and duplications. ${ }^{31}$ The sustained analysis of such debates allows for a nuanced exploration of the British chapter in Snuffs legacy, and how the video release(s) of the film, and the enduring appeal of the tape(s) among horror fans, have meaningfully contributed to the wider mythology of the snuff movie.

Kate Egan, drawing on the work of Kerekes and Slater, has argued that, at one time, collectors of video nasties prioritized seeking out uncut copies of contentious films: what Egan calls the "most politically authentic version of a banned title." However, given the further proliferation of many of the video nasties on DVD and Blu-Ray, collectors nowadays tend to "focus on the historically authentic value of such videos." That is to say, in contemporary collecting culture, less of an emphasis is placed on the films, with more of an emphasis being placed on owning original, authentic cassettes_including artwork and shell cases-from the early 1980s. Egan argues that this underscores recognition of "the marked importance of the original videos' cultural history and their re-constituted status as 'origin objects' within British horror video collecting culture." 32 However, because there is so much confusion surrounding the release of Snuff, and whether or not the version that initially made it onto the market was a bootleg, this surely begs the question: which, out of the blue-sleeved and black-sleeved versions, constitutes the "origin object"? Indeed, if, as David Blight (summarizing the work of Charles Lindholm) has suggested, "authenticity is generally regarded as an absolute valuethe authentic is consistently superior to the inauthentic," 33 then no such "absolute value" can be applied to the UK release(s) of Snuff.

For some fans, the blue-sleeved version is the more dubious of the two. This is because, although an image of the blue-sleeve artwork (replete with Astra insignia) did appear in an issue of the consumer magazine Video Viewer in early 1983 (Figure 6.4)-leading many to speculate that some promotional copies that were never intended for general distribution made it onto the market-none of the collectors I have contacted recall having seen physical copies of the tape in rental shops during the video-nasty era. In fact, according to a lengthy discussion thread on the Pre-Cert Video forum, physical copies of the blue-sleeved variant did not begin to emerge until the early 1990s, with the rise of fanzines (and their classifieds sections, where video tapes could be openly bought, sold, or

\footnotetext{
${ }^{31}$ For detailed insights into the practices of video nasty collectors, see Egan, Trash or Treasure?, 154-81; and Kerekes and Slater, See No Evil, 287-313.

${ }^{32}$ Egan, Trash or Treasure?, 158.

${ }^{33}$ David Blight, Niche Publications and Subcultural Authenticity: The case of Stealth magazine, unpublished thesis, the University of Sydney, 2008, accessed March 31, 2014, http://ses.library.usyd. edu.au//bitstream/2123/3930/1/davidblight_08_honsthesis.pdf.
} 


\section{Tougher times on the way for Nasty distributors}

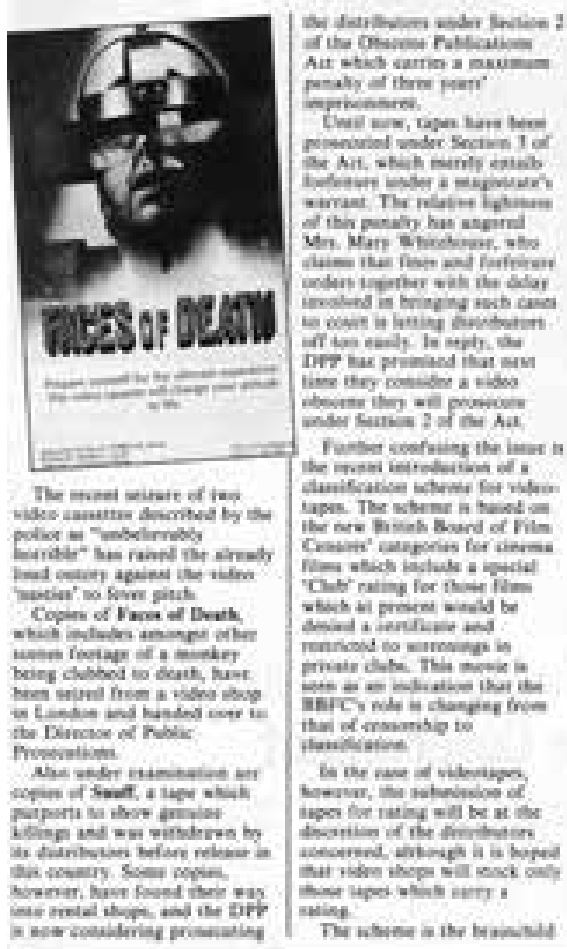

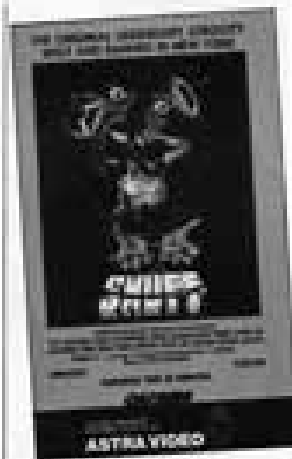

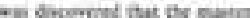
wer thoer abich ithe dosli-

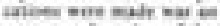

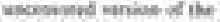

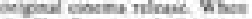

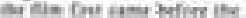

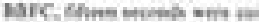

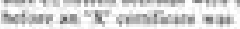
grasted.

And in a trone ind by

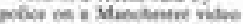
Aog. weveal soples af Yollen. leve oen poeshicused we

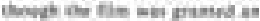

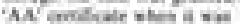

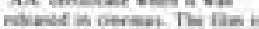
in lact a Girly noceose.

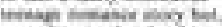

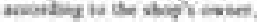

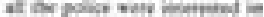

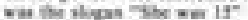

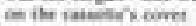

A the vlaps worker hess

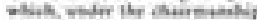

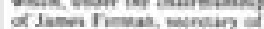

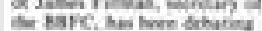

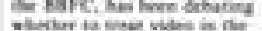

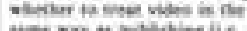

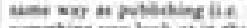
cimentiey you bed at is De

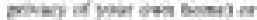
be lepalue be a ibe ber cover.

The itus iten its clande.

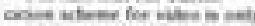
a bulutary roincrice awn te

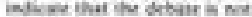
yen wabe Cenviaby the diethloters ibrewhes mes: conlined and warn whrn at

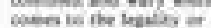

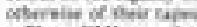
Theors-EMT maceity merdind deckints in inters of

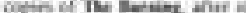

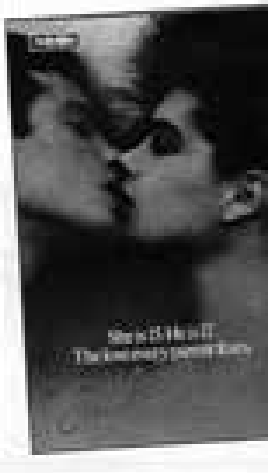

FIGURE 6.4 An article in Video Viewer features an image of "blue-sleeve" Snuff.

traded) and film memorabilia fairs (where video nasties were often sold "under the counter").$^{34}$ Because of this, forum members have gone to great lengths to

\footnotetext{
${ }^{34}$ As Marc Morris argued on the forum: "All known blue sleeve variants were not known to any collectors prior to the early 90s," September 5, 2011, accessed March 31, 2014, http://pre-cert.co.uk/ forum/showthread.php?t=26047\&highlight=blue+snuff. This is a position supported by a number of forums members, and even Behr himself, who has suggested that, "Charles Band, the rights owner, probably shipped them [the blue sleeves] to Belgium [in the 1980s], and that further illicit copies entered the UK from there" (Behr quoted in Wingrove and Morris, The Art of the Nasty, 239). On British horror film fanzines in which video nasties were sold and/or traded, see Kerekes and Slater, See No Evil, 287-313 and Egan, Trash or Treasure?, 106-27; on film fairs and video nasties see Video Nasties 2: Draconian Days.
} 
examine each other's copies of blue-sleeved Snuff, to determine any factors that may either expose their tapes as "dodgy" fakes, ${ }^{35}$ or to confirm their authenticity.

The main area of scrutiny relates to printing inconsistencies, including typeface and punctuation irregularities, color variation, pixelation, and other deficiencies (such as the appearance of crinkles and white marks), which infer that the bluesleeved covers may have been produced in a later period, from a damaged or reproduced master copy. ${ }^{36}$ Such debates, because of their prevalence, have raised enough of a question mark over the provenance of the blue-sleeved version to lead to a ban being imposed by Pre-Cert moderators on all sales until further information arises that can legitimize its release. A result of this is that the blacksleeved version, which has continued to circulate among collectors over thirty years, which definitely was available to rent in the 1980s, and yet which was thought at the time to be a bootleg, has paradoxically become regarded, by some, as the original-and thus "authentic" — release. It has been imbued with a sense of authenticity precisely because it "came first" chronologically. This is irrespective of whether or not Astra was involved with the release. Yet, while the "bootleg" may ironically have been granted an aura of legitimacy in some corners of video-nasty fandom, the fact that its origins remain unknown, complicates the application of an "absolute value."

In November 2013, it appeared as though fans' questions were about to be answered. An eBay auction advertised an "original" poster for the UK video release of Snuff, ${ }^{37}$ which the seller claimed to have purchased from a video shop in Birmingham in 1983. ${ }^{38}$ The poster utilized all the elements of the black-sleeved artwork-the same image, the same 3-D title, the same tagline-though crucially incorporated two important new additions: the logos for both Astra and Wizard. Collectors on the Pre-Cert forum steered clear of the auction, due partly to the worn condition of the poster and high reserve price of $£ 200.00$, but mostly because of speculation from some forum members that it simply could not be genuine, because, to their mind, Astra never officially released the film in the first place. ${ }^{39}$ As one Pre-Cert member suggested, he would have expected the poster

\footnotetext{
${ }^{35}$ As one forum member has it, following the first alleged appearance of blue-sleeved Snuff in the 90s, "more appear[ed] via eBay and trade lists" in the period after, including, "a number of known dodgy copies, in the 2000s." See "SNUFF Blue Sleeve," June 14, 2010, accessed February 7, 2014, http://www. pre-cert.co.uk/forum/showthread.php?t=16562.

${ }^{36}$ See the following threads for lengthy discussions: "Black Snuff: Snide or Pride?" July 7, 2011, http:// pre-cert.co.uk/forum/showthread.php?t=24511\&highlight=blue+snuff\&page=2; "SNUFF or F for Fake!," June 10, 2010, http://pre-cert.co.uk/forum/showthread.php?t=16454\&highlight=blue+snuff, and "SNUFF Blue Sleeve." All accessed May 5, 2014.

${ }^{37} \mathrm{http}: / /$ www.ebay.co.uk/itm/151154244637?clk_rvr_id=827275770339\&rmvSB=true.

${ }^{38}$ Graham Foley.e-mail exchange with author, November 17, 2013.

39"Lastmarine," "Now Then, Now Then, Now Then: SNUFF Astra Video Poster!" October 30, 2013, accessed January 12, 2014, http://www.pre-cert.co.uk/forum/showthread.php?t=40761.
} 
found on eBay "to have been publicising a BLUE sleeved Snuff," 40 because that was the version which was known to have had originally carried the logos and other company information. The fact that the poster bore more similarity to the "unofficial" release, encouraged some to consider the emergence of the poster proof "that Astra were [sic.] behind the black sleeve release" after all. ${ }^{41}$

It is perhaps precisely due to the fact that no one is able to verify whether or not the blue-sleeve version circulated in the early 1980s, nor whether Astra were indeed behind the black-sleeve release, that the mythology surrounding Snuff has been compounded. These ongoing debates demonstrate that, as Belk has observed, collecting is "a shared passion that transcends utilitarian concerns," 42 indicating an investment beyond the simple acquisition of a desired object. As shown in this section, video-nasty collectors debate information within their shared community, which is then analyzed in terms of its validity in relation to the known/unknown parts of an object's history. From the individual desire to solve the "mystery" of Snuff's British release, to the sharing of knowledge within the community, or even the less altruistic motivation of simply maintaining the monetary value of particular versions, ${ }^{43}$ there is continued investment from collectors into the mystery of this notorious enigma from British history.

\section{Of artifacts and artifice: Conclusion}

George Plasketes, writing about vinyl record collecting, has claimed that:

the passage of cultural icons [...] and their accompanying artefacts and products, can often result in the emergence-or submergence-of a subculture, made up of those who [...] determinedly cling to the artefact, collecting or preserving a part of it because of the meaning and experience contained within. ${ }^{44}$

Such a process of subcultural preservation would appear to resonate with the discourse surrounding the video-nasty collectors discussed in this chapter. As Egan has observed, the meanings attached to the nasties have changed over time; with the term itself having being used to describe, "a set of film titles, a specific

\footnotetext{
40"Bigandy," "Now Then, Now Then, Now Then".

41" Hellochas," "Now Then, Now Then, Now Then".

${ }^{42}$ Russell Belk, Collecting in a Consumer Society (London: Routledge, 2001): 35.

${ }^{43}$ See, for example, "Scorpio," "SNUFF (BLUE ASTRA)," September 23, 2010, accessed May 11, 2014, http://pre-cert.co.uk/forum/showthread.php?t=18497\&highlight=blue+snuff.

${ }^{44}$ George Plasketes, "Romancing the Record: The Vinyl De-Evolution and Subcultural Evolution," Journal of Popular Culture 26, no. 1 (1992): 109-22.
} 
set of video versions, a set of historical events and a personal consumption experience." ${ }^{45}$ In a recent interview, Jake West, the director responsible for the aforementioned Video Nasties documentaries, spoke nostalgically of the early 1980s, stating that, "as much as [I am] opposed to censorship, it gave [my] generation of film viewers a thrilling sense of the forbidden." ${ }^{46}$ West here acknowledges the retrospective, generational, creation of a community in direct opposition to the legislative frameworks governing home-viewing in the UK. This is a view reiterated by Mark Meakin in a recent online poll charting the decline in the censorship of horror films in the UK. Meakin attributes the relaxation of the censors largely to the development of the Internet, stating that "nothing is hard to get but it takes the fun out of trying to get hold of stuff like the good old (well, bad) days." 47

The "personal consumption experience" of the video-nasties collector demonstrated by both West and Meakin is irrevocably linked with a sense of the illicit and the "forbidden" opportunities provided by the "video nasties." However, as we have seen, the search for the "historical authenticity" of the video nasties is also a primary factor for many video-nasty fans: not least, in the highly contentious case of Snuff. Indeed, as Desmond Coke suggested in 1928, in his book Confessions of an Incurable Collector:

It must not be thought, though it too often is, that the collector's only joy is in the actual buying. When he [sic] has got his purchase ... the real fun is only just the beginning. There is the closer inspection than was possible; the showing to a fellow expert (spare your other friends); the choice-and making-of a place to put it. ${ }^{48}$

For collectors of the video nasties, the "real fun" is in the learning and transmitting of knowledge related to the origins and legacy of certain video releases. These kinds of readings hold considerable weight in the collecting community. In the case of Snuff, debates transcend the simple acquisition of an object, moving into arenas where collectors can interpret a history that is in a continual state of renegotiation. The ongoing discussions around Snuff, therefore, afford collectors an opportunity to scrutinise the most contested parts of that history, while in the

\footnotetext{
${ }^{45}$ Egan, Trash or Treasure?, 5.

${ }^{46}$ Laurence Phelan, "Film Censorship: How Moral Panic Led to a Mass Ban of 'Video Nasties', The Independent, July 13, 2014, accessed July 14, 2014, http://www.independent.co.uk/arts-entertainment/ films/features/film-censorship-how-moral-panic-led-to-a-mass-ban-of-video-nasties-9600998.html. ${ }^{47}$ Dracucarr, "POLL HELP: Video Nasties and Censorship," Cult Movie Forums, accessed July 20, 2014, available at: http://www.cultmovieforums.com/forum/threads/poll-help-video-nasties-andcensorship.11300/page-5.

${ }^{48}$ Demond Coke, Confessions of an Incurable Collector (London: The Whitefriars Press, Ltd., 1928): 16.
} 
process, contributing to its ongoing examination, redefining themselves not only as archivists and custodians but as historians, too. ${ }^{49}$

Early publicity material promoting Snuff asked us to question "Are the killings in this film real?" This is the question which loomed over the film's release in America, and, as this chapter has shown, prevented the pinning down of an official, traceable history of its release in the UK. It was also a question that, as Julian Petley notes, was a primary concern for the British press throughout the 1990s, namely, when hyperbolic reports first began to come in about the videonasty black market and those horror fans participating in it. ${ }^{50}$ Yet, this is not the question that has prompted the most intrigue from British video collectors. Rather than being concerned about the film's supposed veracity, instead, collectors have debated at length the film's distribution history in the UK. And while, for the broader public, such information may seem trivial when confronted with a film purporting to show the genuine death of a human, the questions posed by Snuffs shady presence on the UK video market has added a new, and decidedly national, dimension to cultural mythology of the snuff movie.

\footnotetext{
${ }^{49}$ Egan, Trash or Treasure?, 175.

50“'The story of 'snuff' in Britain clearly demonstrates how the constant peddling of a myth has succeeded not only in legitimating excessive censorship but also in criminalising those who collect horror videos and even tarnishing them with the taint of paedophilia." Petley, "Snuffed Out," 219.
} 